as agricultural areas would not be interfered with and would continue, as shown in the development plan, in their existing use. Before the decision of the Minister of Town and Country Planning could be promulgated, and within less than seven months from the inquiry, the Branch reports that Sheffield City Council has adopted a resolution to change certain provisions in it and to allocate portions of this land for building, without formal amendment or a public hearing. It would appear, therefore, that 'unallocated' land in a development plan can be developed at any time. If this is not the case an official assurance to the contrary would be welcomed.

\section{Numbers of Man and Animals}

THE Institute of Biology is organizing a symposium under the general title "The Numbers of Man and Animals", to be held at the Royal Geographical Society, London, during September 24-25. The symposium is to be opened by Sir Alexander CarrSaunders, and the first session will be concerned with the varied approaches of the economist, demographer and anthropologist, papers being given by A. T. Peacock, E. Grebenik and Prof. I. Schapera. The second session (chairman, Prof. C. H. Waddington) will begin with a study of the mathematical approach to population dynamics by Mr. J. G. Skellam. Dr. D. S. Lack, D. H. Chitty and Prof. T. Park (Chicago) will then deal with various aspects of the study of animal populations. The third session (chairman, Prof. J. Z. Young) will be concerned with the effects of disease, fertility and nutrition on the structure of populations. Papers are to be given by Dr. A. S. Parkes, Prof. A. L. Banks and Dr. J. Hammond. In the final session (chairman, Prof. S. Zuckerman) Dr. Fraser-Darling is to speak from the point of view of the ecologist, Prof. L. S. Penrose will discuss changes in the quality of human populations and Lord BoydOrr will comment on the future outlook. Copies of the various papers will be available some weeks before the meeting. Further information can be obtained from the General Secretary, Institute of Biology, Tavistock House South, Tavistock Square, London, W.C.1.

\section{Ninth Electronics Course at Harwell}

Applications are invited by the Atomic Energy Research Establishment, Harwell, from physicists and electronic engineers holding a degree or equivalent qualification, who wish to attend the ninth electronics course. The course covers the design, use and maintenance of electronic instruments used in nuclear physics, radiochemistry, and in work with radioisotopes. It is to be held at the Isotope School, Harwell, during November I-5. Attendance at the course is limited to 12 students. The syllabus will include lectures and practical work concerned with counters, D.C. and pulse amplifiers, coincidence units, scalers and ratemeters, and the lecturers and demonstrators will be specialists from the Atomic Energy Research Establishment. The fee for the course is twelve guineas, and living accommodation can be arranged locally at a charge of five guineas approximately. Further information can be obtained from the Electronics Division, A.E.R.E., Harwell, Didcot, Berks. Application forms must be returned by October 15.

\section{Announcements}

THE Royal Society of Arts has awarded the R. B. Bennett Empire Prize of 100 guineas for 1954 to
Dr. C. J. Mackenzie, president of the Atomic Energy Control Board, Canada. The Prize was founded in 1945 by the late Viscount Bennett, a former president and chairman of council of the Royal Society of Arts, and is awarded every three years "for the most outstanding contribution from the Dominions, India, Burma and the Colonies, to the promotion of the arts, agriculture, industries and commerce of the overseas empire during each intervening period".

Dr. A. FröHLICH, lecturer in the University College of North Staffordshire, has been appointed to the University readership in pure mathematics tenable at King's College, University of London.

THE annual conference of the Society of Leather Trades' Chemists will be held in the Large Chemistry Lecture Theatre, University of Leeds, during September 24-25. On the afternoon of the first day, the sixth Procter Memorial Lecture of the Society will be delivered by Prof. J. T. Randall, Wheatstone professor of physics, King's College, University of London, his subject being "Observations on the Collagen System". Further information can be obtained from the honorary secretary, G. H. W. Humphreys, Forestal Central Laboratories, Harpenden, Herts.

From August 18 until the end of the year, the Science Museum will be showing some of the most important books on astronomy which were published between the fifteenth and the middle of the nineteenth centuries. The exhibition will include copies of Newton's "Principia", Copernicus's "De Revolutionibus Orbis", as well as works of Tycho Brahe, Kepler, Halley and Herschel. The exhibition will include photographs of many of the illustrations in the books. The Royal Astronomical Society has lent a number of books from its library to supplement the Science Museum's own collection.

A course on the measurement of the particle-size characteristics of fine powders will be given by Dr. H. E. Rose in the Faculty of Engineering, King's College, University of London, during the week commencing September 27. The course is primarily intended for graduates engaged in industry and will consist of a series of lectures, tutorials and demonstrations in the more common techniques for the determination of the size-characteristics of powdered materials in the sub-sieve range. The fee is five guineas. Forms of application should be returned not later than September 10, and further information can be obtained from the Dean of the Faculty of Engineering, King's College, London, W.C.2.

The X-ray Analysis Group of the Institute of Physics will be holding its autumn conference during October 22-23 at the Royal Institution, Albemarle Street, London, W.1. The subjects to be dealt with at the conference will be the structure and texture of metals. There will be an evening discourse on October 22 by Prof. A. H. Cottrell on dislocations. The conference is open to all, without charge, on completion of an application form, copies of which can be obtained from the Deputy Secretary, Institute of Physics, 47 Belgrave Square, London, S.W.1.

WE regret that Sir Harold Hartley's signature was inadvertently omitted from the obituary notice of Dr. O. J. R. Howarth published in Nature of August 7, p. 249, although it appeared in the list of "Contents". 